\title{
Facies Analysis and Depositional Environment of Khurmala Formation in Bekhair Anticline-Dohuk Area, North Iraq
}

\author{
Nabil Y. Al-Banna \\ Dams and Water Resource \\ Research Center \\ Mosul University
}

\author{
Majid M. Al-Mutwali \\ Department of Geology \\ College of science \\ Mosul University
}

\author{
Jamal S. Al-Ghrear \\ Department of geology \\ College of Science \\ Mosul University
}

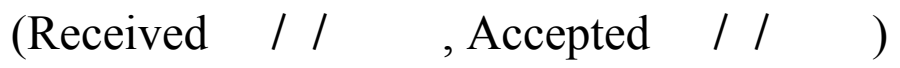

\begin{abstract}
The studied surface section of Khurmala Formation which lies in the northeast of Dohuk city north Iraq consists of mixed carbonate and clastic sediments, package about 60 meter thick of Early Eocene age. The carbonate sediment is comprising four microfacies association allocated to shoal bank (Kh2), lagoon (Kh1), intertidal (Kh1, Kh3), and supratidal (Kh4), while the clastic sediment included two lithofacies affiliated to estuaries depositional environment. A depositional model of the Khurmala Formation was proposed.

Diagenetic processes of dissolution and dolomitization are recognized in microfacies $(\mathrm{Kh} 3)$.
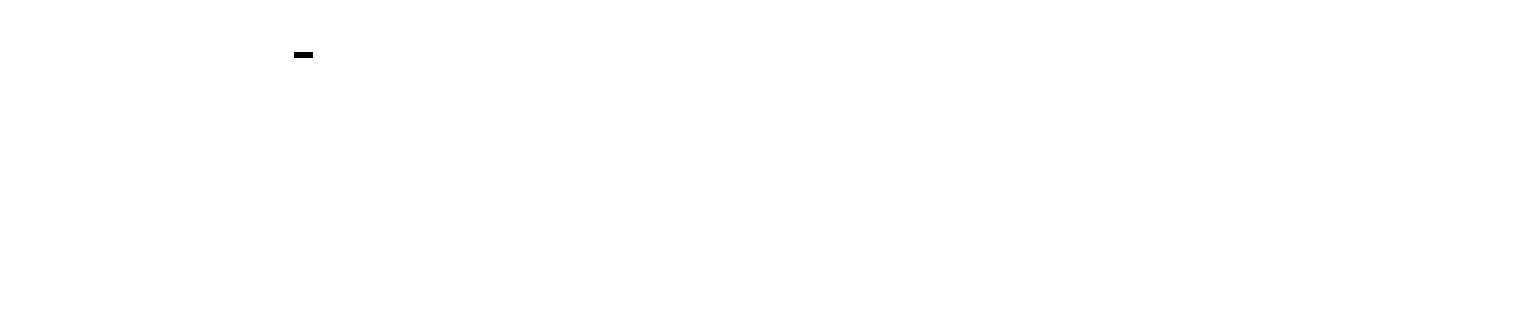

درس مقطع تكوين خورمالة المنكثف على الجناح الشمالي لطية بيخيرشمل شرق مدينة دهوك،

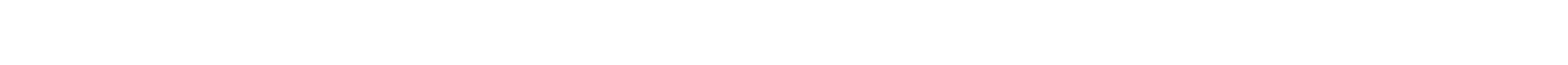

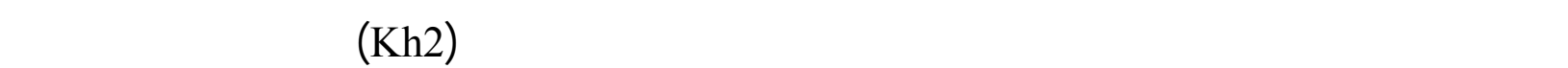

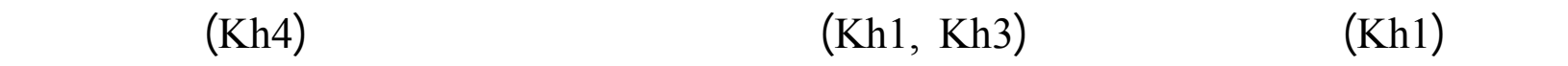

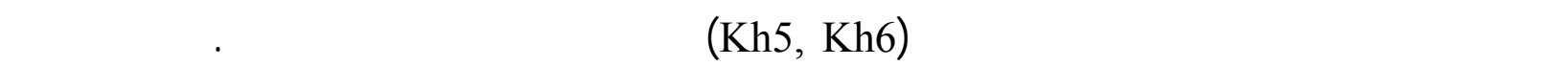

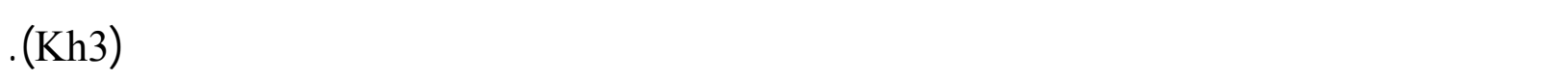

\section{INTRODUCTION}

Surface section of the Khurmala Formation has been studied in the northeast of Dohuk city north Iraq (Figure 1). Khurmala Formation was described for the first time by Bellen, 1953 (in Bellen et al., 1959) in well K-114 at Kirkok area. The formation embraces oolitic dolomite and recrystalline limestone, these beds are interfingering with sandstone beds (from the older Kolosh Formation), containing chert, flint, radiolarite and greenstones of silt and sand size. Anhydrite (probably secondary) occurs sporadically too (Bellen et al., 1959).
\end{abstract}


All previous researches that deal with the sedimentology and biostratigraphy of Khurmala Formation (Kassab, 1978; Abdul-Muniam and Said, 1979 and Al- Eisa, 1983) mentioned that the sediments of Khurmala Formation are found as tongues within upper part of Kolosh Formation (Early Eocene age) in different parts of north Iraq.

Microfacies analysis of the formation was carried out, depositional environments were infered and sedimentary model is constructed for the formation.

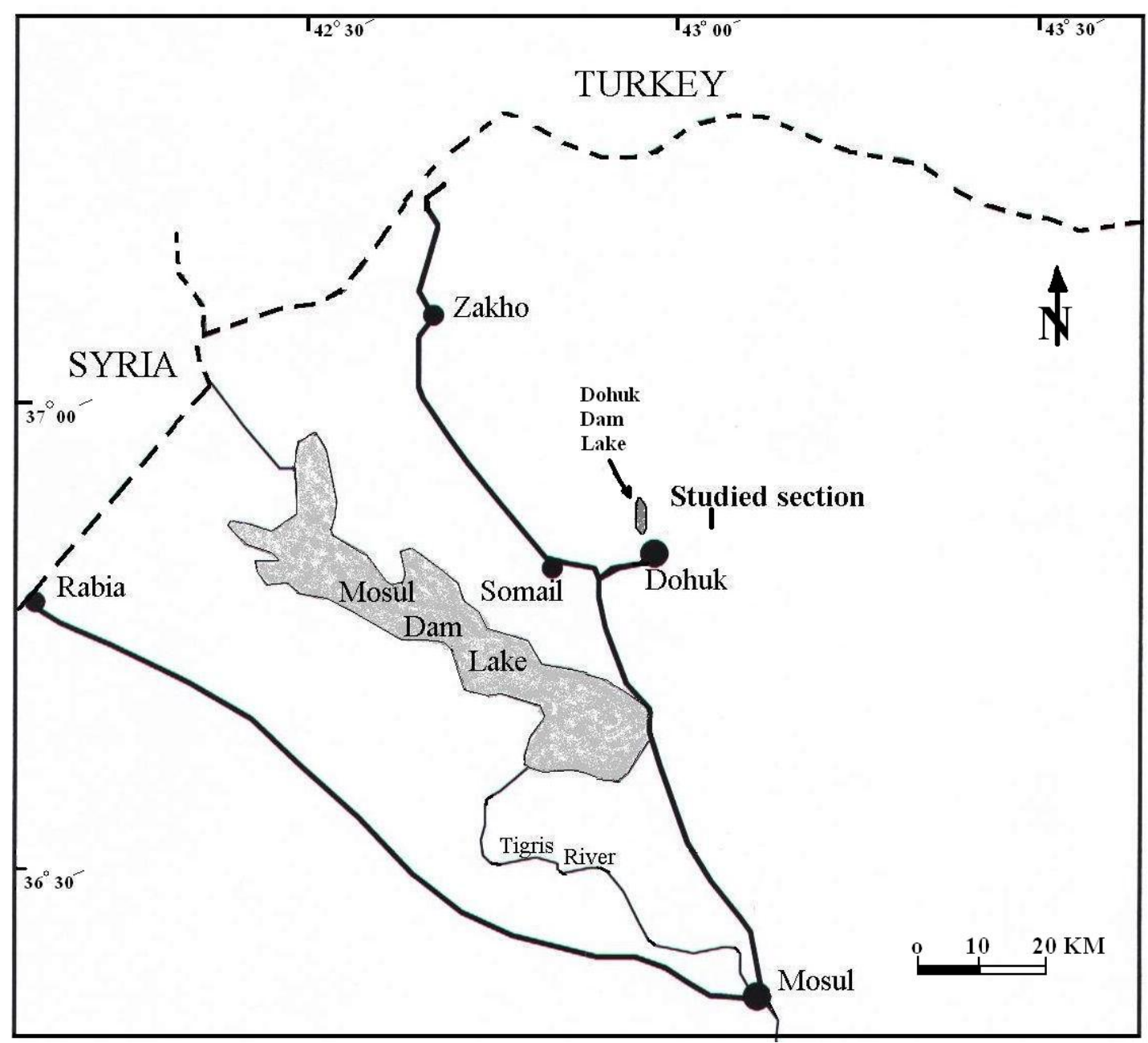

Figure 1 : Location map of the study area.

\section{LITHOSTRATIGRAPHY}

A total of twenty six samples from the $70 \mathrm{~m}$ thick succession of which $60 \mathrm{~m}$ belong to Khurmala Formation were processed for sedimentary facies and foramineferal analysis. Lithologically, sedimentary structures and macrofossils records were taken into account. The samples were collected at a maximum interval of about $4 \mathrm{~m}$.

The lower boundary is sharp with the Kolosh Formation (Plate 1). Which consists of claystone and gray marl (Plate 1; Figure 2). Lithologically, the lower part of Khurmala Formation embraces brown argillaceous limestone of $16 \mathrm{~m}$ thick, it's base is recognized by the occurrence of large gastropod. The overlying bed included 6 meter of pale brown terrigenous mudstone. It is followed by 18 meter of sandstone embracing thin bed of argillaceous limestone and lenses of channel filled conglomerate with maximum width of 2 meter. In addition small scale cross-bedding and horizontal lamination were recognized in the sandstones. 
Beds of argillaceous limestone appear at 44-45 meter interval, where it's shows partial dolomitization and contains vugs and small caverns. A thin sandstone bed is sandwiched at 48 meter level. The upper surface of the limestone shows occurrence of bird legs fossils and grazing trace. They are followed by 12 meter thick of brown mudstone which engulfs 1 meter of hard limestone at 58 meter level. The upper boundary of Khurmala Formation is sharp with the overlying red-coloured sandstone of Gercus Formation which also embraces dark gray conglomerate (Plate 2)

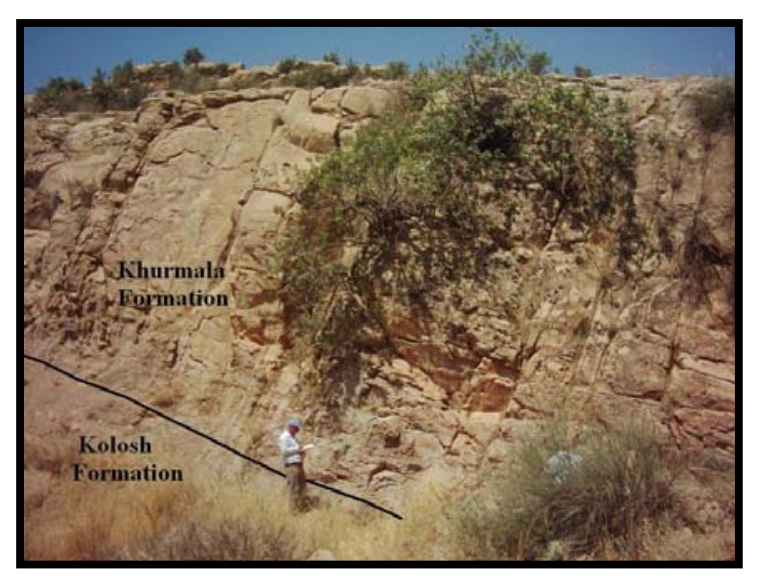

Plate 1: The boundary between Khurmala Formation and Kolosh Formation.

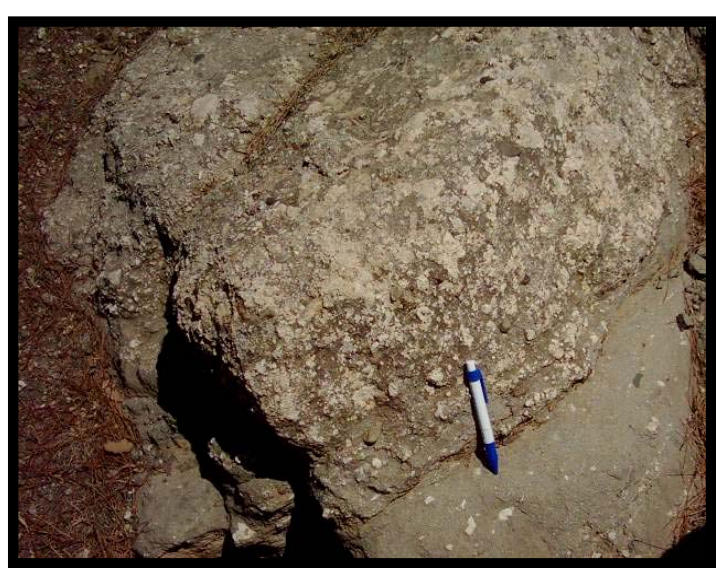

Plate 2: The conglomerate bed of Gercus Formation, sample 26.

\section{SEDIMENTARY FACIES}

The Khurmala Formation is comprised of two varieties of sedimentary facies namely carbonate and clastic; the carbonate embraces four microfacies and the clastic includs two lithofacies (Figure 2):

\section{Microfacies:}

Microfacies were characterised according to Dunham (1962) classification; they are as follow:

\section{Benthonic lime packstone microfacies (Kh1):}

This microfacies consists mainly of benthonic foraminifera. The allochems percentage ranging between $70-80 \%$ of the total microfacies content. The benthonic foraminifera are represented by miliolids (Quinqueloculina, Triloculina, Pyrgo and Spiroloculina) Rotalia trochidiformis, Lockhartia sp., Valvulina spp., Anomalina spp., Textularia sp., Peneroplis sp. and Ammobaculites sp., in addition to green algae, red algae, echinoides, ostracod and rare small gastropods. Large gastropods are common in the lower part of the microfacies (plate 3). The total biocontent percentage ranging between $80-90 \%$ of the total allochems. The lithoclast consist of scattered grains of minerals and rock fragments ranging between $10-20 \%$ of the total allochems, the minerals include gluaconite, feldspar, Ca-plagioclase, opaque mineral, chert, polycrystalline quartz, pyrite, zircon and monazite (Plate 4). These minerals are analogous to those present in Kolosh Formation sandstone content. 


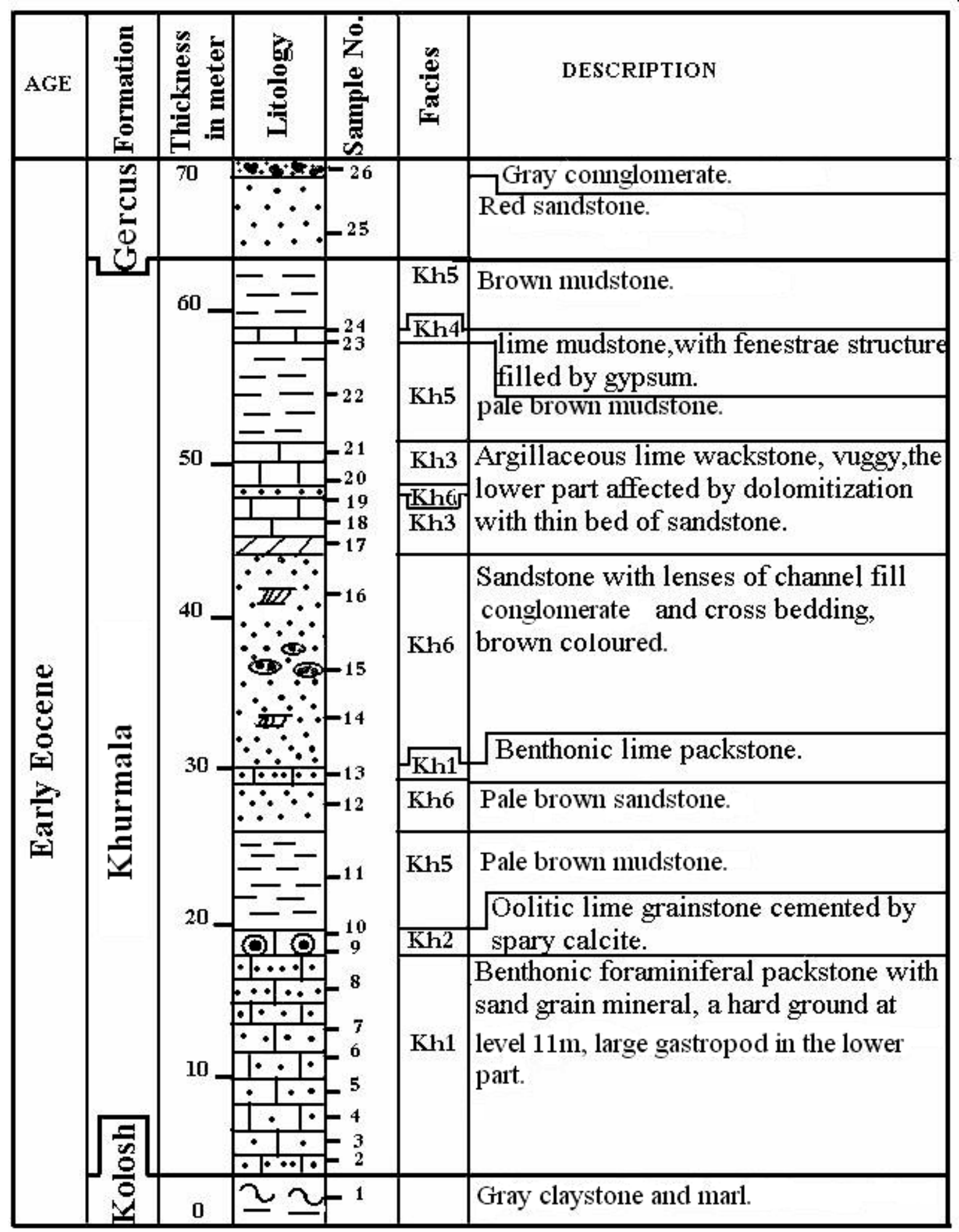

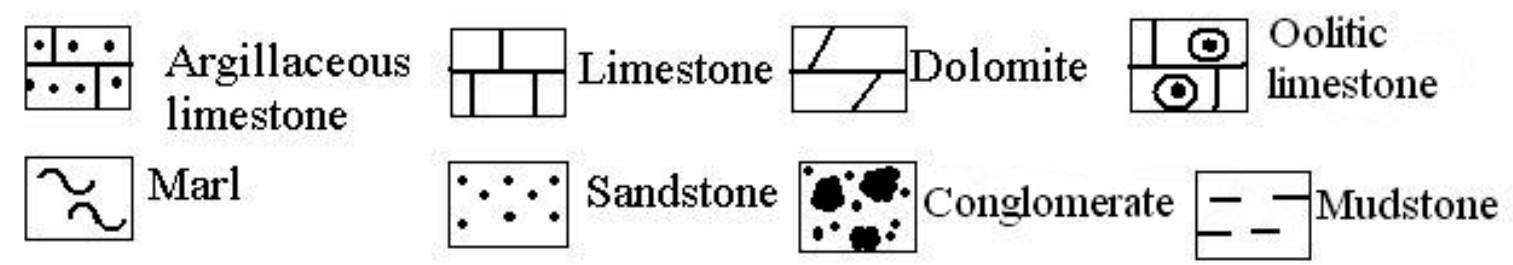

Figure 2: Lithologic description of the studied section. 

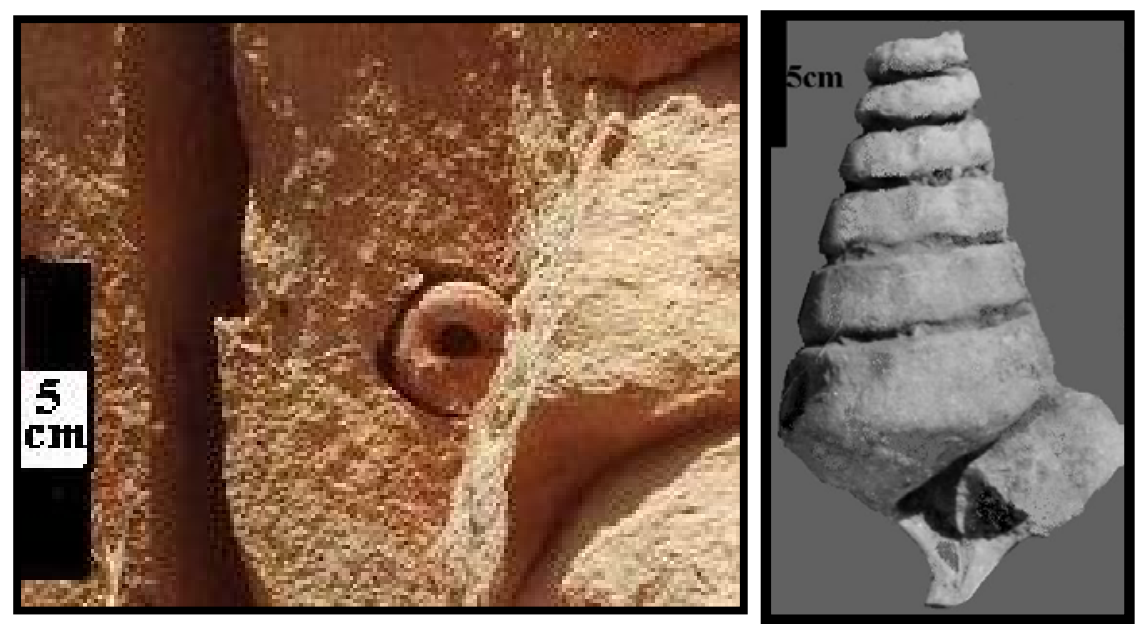

Plate 3 : large gastropod fossils.

The percentage of Rotalia trochidiformis and Lockhartia sp. indicate warm shallow water with depth less than 40m (Levin, 1957). The co-occourrence of Rotaliids, miliolids (Quinqueloculina, Triloculina, Pyrgo and Spiroloculina) Textularia, echinoids (spines and plates), green and red algae (Plate 5) and gastropoda indicated for shallow warm water of costal lagoonal environment with depth less than $40 \mathrm{~m}$ (Murray, 1973 ; Hedley and Adams, 1976 and Pettars, 1979). The detrital sand grains content influx from the nearby tributaries and the absence of any of evaporite minerals are evidence of diluted moderate salinity environment.

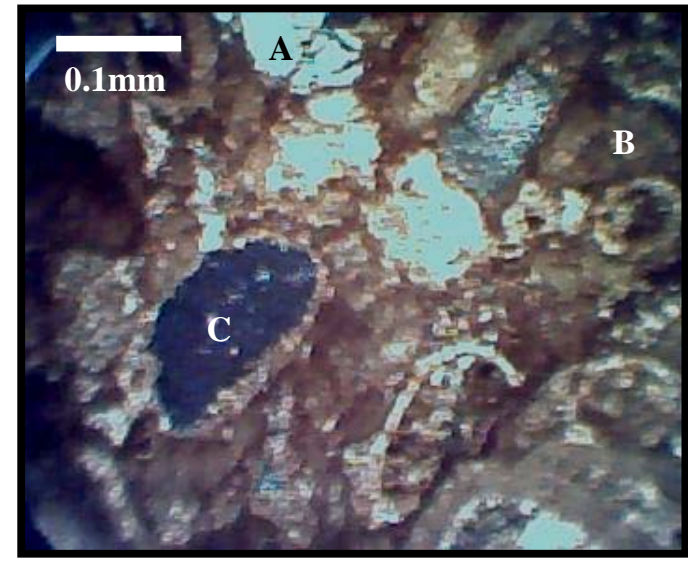

Plate 4: Sand grain mineral, (A)quartz, (B) sedimentary rock fragment, (C) glauconite. Sample 7.

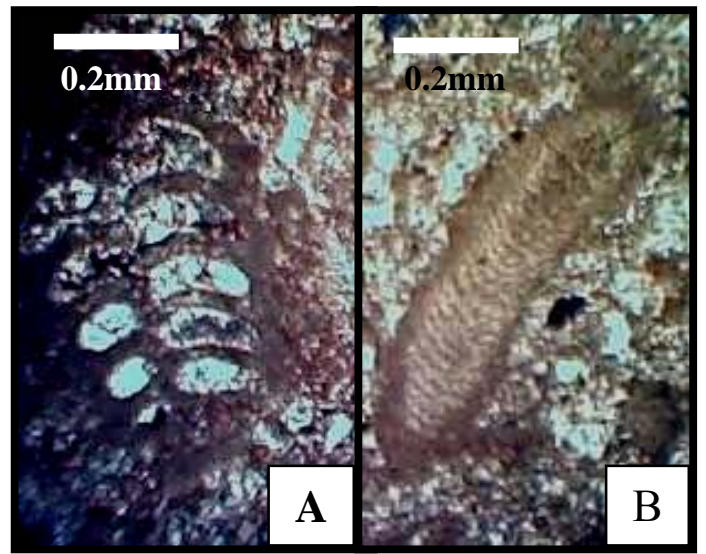

Plate 5: (A) Textularia sp., (B) Red algae, Sample 3.

\section{Oolite lime grainstone microfacies: (Kh2)}

The main contents of the microfacies are ooid grains; consisting of foraminifera or lithoclast as nucleus coated by micrite layers forming tangential structure ooids. The matrix represented by sparite crystal filling all the space between allochems (Plate 6) and with the lack of micrite should indicated a high energy shallow water environment (Flugel, 1982). The total thickness of the microfacies is about $1 \mathrm{~m}$. these features indicated shoal bank and tidal bar environment and can be matched with SMF15 within FZ6 (Flugel, 1982). 


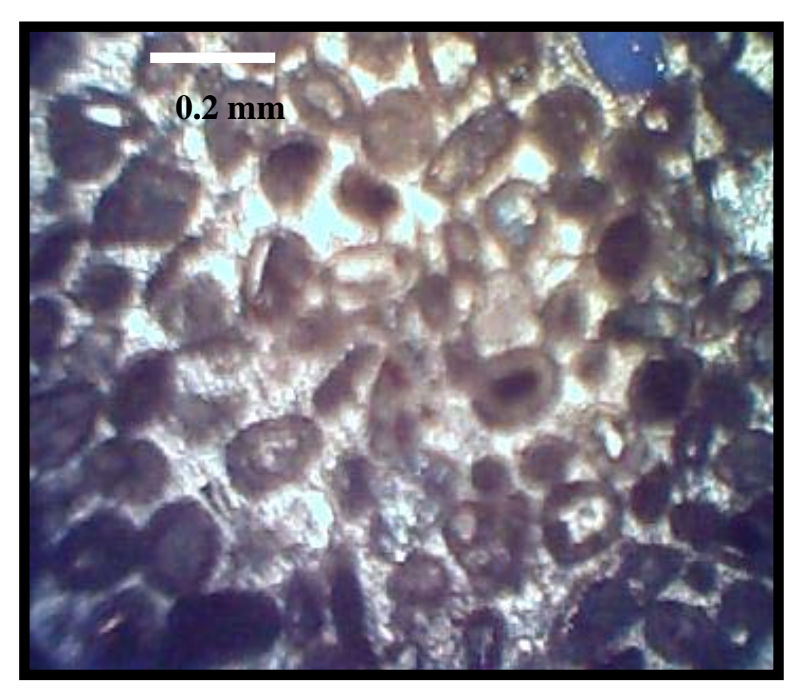

Plate 6: Oolite grains cemented by spary calcite, Sample 10.

\section{Argillaceous Lime wackestone microfacies: (Kh3)}

The microfacies contains benthonic foraminifera. Generally, these forams are vague and hard to be recognized because of dissolution that effected this microfacies. Nevertheless gosts of Peneroplis and Textularia were recognized, In addition there are scattered sand size mineral grains whose contant ranges between 10-20\%. They are represented by chert, hornblende, magnetite, plagioclase and quartz. The matrix consists of micrite.

The lower part of the microfacies was affected by two generations of dolomitization. The first one is fine crystalline dolomite as matrix, while the second consists of medium to coarse crystalline dolomite filling the vuggs and destroying the fossils texture. Generally, the chraacteristic feacture of dolomite bed can be used as an indication of mixing water mechanism of dolomitization (Badiozamani, 1973).

Leg bones fossils of birds found on the upper surface of the microfacies (plate 7) implies that this microfacies is deposited in the marginal marine coastal land.

All the sedimentological and biological evidences of the microfacies indicate a lagoonal and tidal bar environment and it can be correlated with SMF 18 of FZ8 (Flugel, 1982).

\section{Lime mudstone microfacies: (Kh4)}

The microfacies is homogenous and consists of micrite with very rare fossils and scattered small vugs sometimes filled by gypsum, These vugs look like fenestrae sedimentary structure which is recognized only in the microfacies (plate 8). The total thickness of this microfacies is 1 meter.

All these features indicate a supratidal environment. Generally this kind of limestone is usually affected by syndepositional dolomitization which is not the case, concerned with presently, remained as limestone. This points to a warm but not highly saline sea water (Hus and Siegenthaler, 1969). The microfacies can be correlated by SMF23 in FZ9 (Flugel, 1982). 


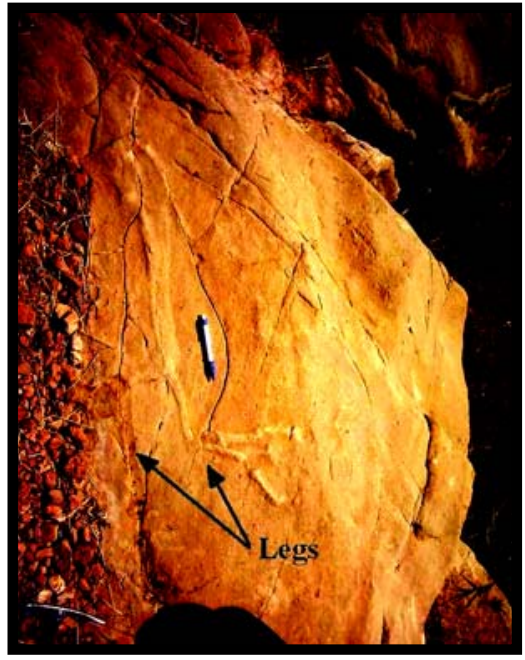

Plate 7: Leg bones Fossils of bird, at 51 meter level.

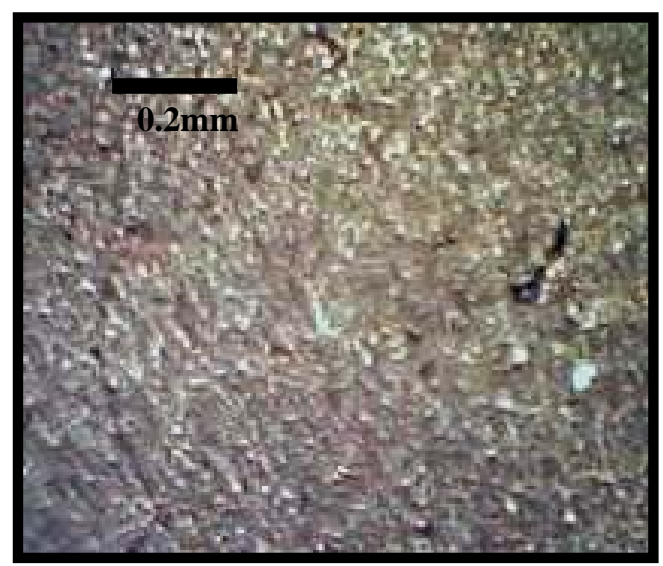

Plate 8: Lime mudstone (micrite) with fenestrae texture $(\mathrm{F})$, sample 24 .

\section{Sandstone lithofacies: (Kh5)}

The microfacies consists mainly of immature poorly sorted sandstone, ranging in grain sizes from medium at the lower part and fine grained sandstone at the upper part of the succession, showing an overall fining upward sequences.

According to it's content the sandstone is classified as lithic graywacke (Dott, 1964; Pettijohn et al., 1972).

The frame work grains consist of quartz, chert and sedimentary lithic fragments, in addition to the type of quartz grain inclusion, all these collectively reflected both sedimentary and igneous source rock of sand grains (Folk, 1974). The rich content of lithic fragments and chert as polycrystalline quartz are indicating to the tectonic setting of recycled orogen provenance (Dickinson and Suczek, 1979).

The presence of trough shape small channel filled, small scale cross bedding and parallel lamination (Plate 9-10), are indication of coastal bar deposit (Divedson-Arnott and Greenwood, 1976), in addition to the sligtly fining up ward cycle ended by mudstones. All these evidences indicate that the lithofacies deposited by channel estuaries (Clifton, 1982; Reinson, 1997).

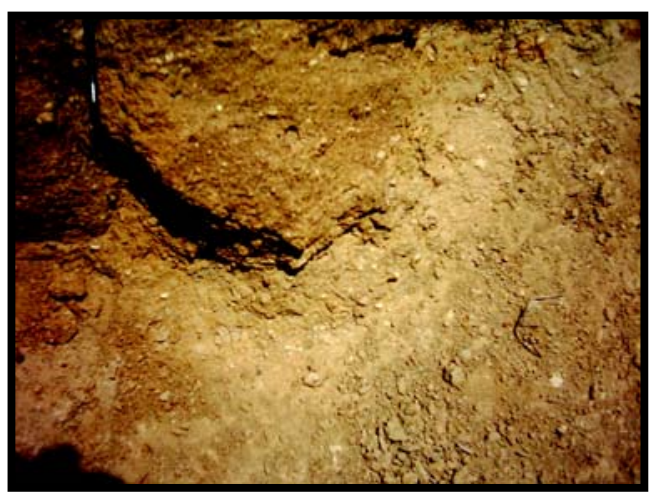

Plate 8: Channel filled conglomerate at 37 meter level.

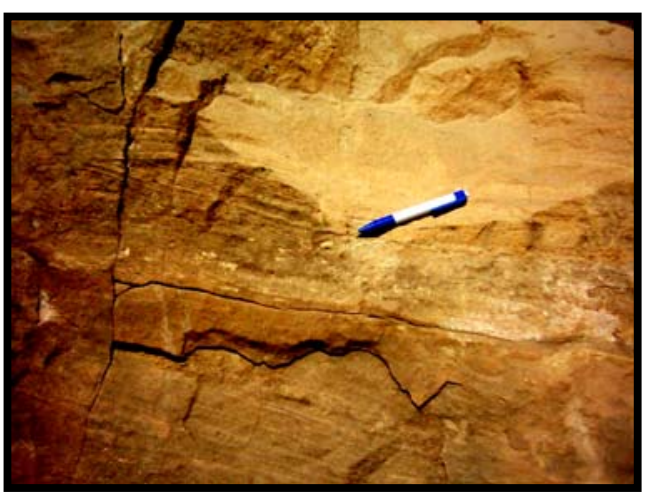

Plate 9: Small scale cross bedding at 42 meter level. 


\section{Mudstone lithofacies: (Kh6)}

The lithofacies characterized by calcareous mudstone of pale brown colour, it embraces thin beds of siltstone and very fine sandstone at some interval. This type of sediments may be deposit in low energy water generally mud flat adjoining the estuary (Dill et al., 2001) also it may be deposited in quite water body of swamp or abundant channel (Bordy et al., 2004).

The presence of this microfacies associated with sandstone and argillaceous limestone of estuaries and tidal channel may indicate muddy coastal bay environment.

\section{Depositional environment of Khurmala Formation:}

The sedimentary facies encountered are reflecting an assorted depositional environment. The clastic lithofacies represented by two lithofacies (Kh5, Kh6) whose characteristic features and sedimentary structures point to an estuaries or coastal bars depositional environment. The lateral marine equivalent environment represented by shoal bank environment embracing oolite lime grainstone microfacies $(\mathrm{Kh} 2)$ that clearly indicates an active wave dominated shoal. This bank protected a lagoonal bays and tidal bar environment represented by packstone microfacies including part of (Kh1) microfacies with water depth less than 40 meter. The other part of the (Kh1) microfacies and microfacies $(\mathrm{Kh} 3)$ contains argillaceous sand size mineral with their percentage reaching up to $20 \%$ of the total microfacies. These sand carbonate admixtures is affiliated to lateral juxtaposition of estuaries and carbonate rich sedimentation. The tidal flat deposits are recognized as lime mudstone microfacies $(\mathrm{Kh} 4)$ in association with clastic lithofacies (Figure 3).

The succession of depositional environment is analogous to a mixing type-bay (Pautal.1987) where interference of estuaries drift on autochthonous carbonate rich sedimentation.

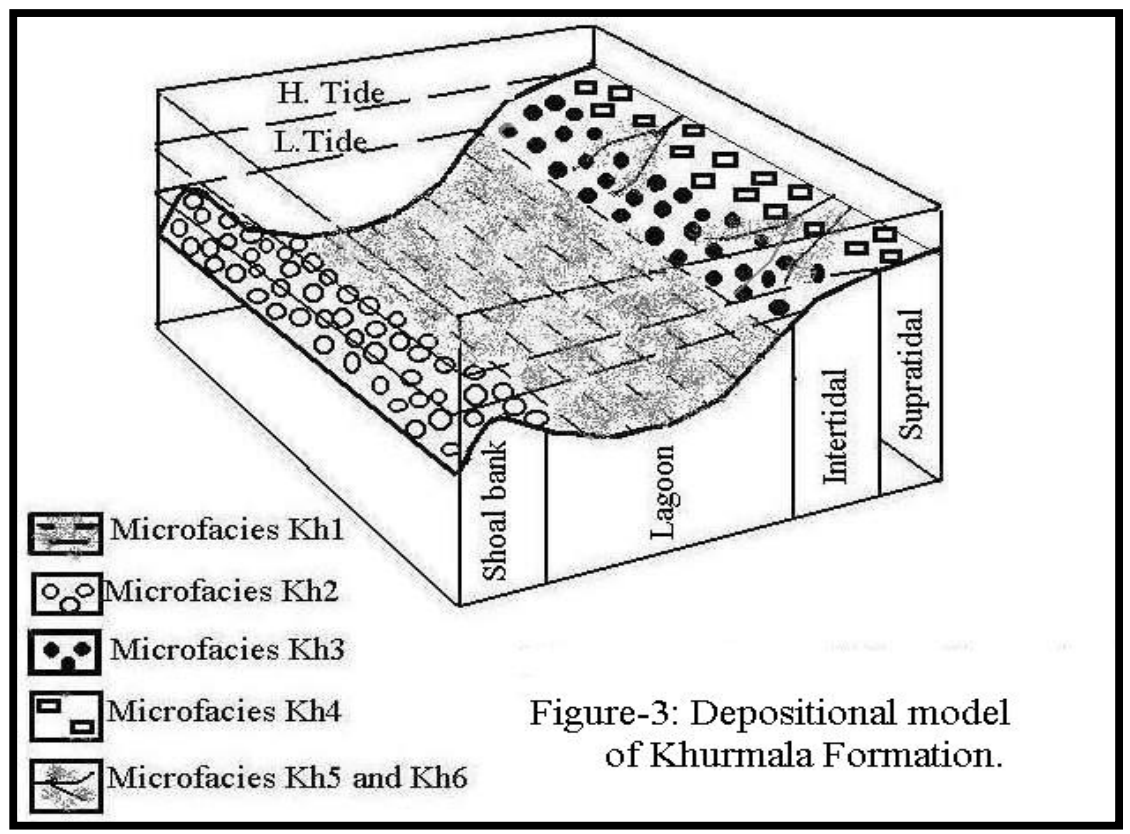

Figure 3 : Depositional model of Khurmala Formation. 


\section{ACKNOWLEDGMENT}

The authors would like to thank Dr. M.A. Amin for reading and improving the manuscript.

\section{REFERENSES}

Abdul-Muniam, A. and Said, V.K., 1979. Micro-Macropaleontology and Large Forams of the Cretaceous and Tertiary Sediment of Erbil, Saqlawa, Koisanja and Raid Areas, North- Iraq. Directed S.O. M. Library Baghdad (unpuplished report) 109p.

Al-Eisa, E., 1983. Study of the Foraminifera and the Depositional Environment of Fossils in the Khurmala Formation, Shaqlawa Area. (unpublished) M.Sc. Thesis, University of Mosul, Iraq. 94p.

Badiozamani, Kh., 1973. The Dorag Dolomitization Model Application to the Middle Ordovician of Wisconsin, Journal of Sedimentary Petrology, Vol. 43, pp.465-484.

Bellen, R.C., Van Dunnington, H.V. and Wetzel, R., 1959. Lexique Stratigraphique International Asie, Fascicule 10a, Iraq-Paris Center National de Ia Recherche Scientique, $333 p$.

Bordy, E.M., Hancox, P.J. and Rubidge, B.S., 2004. Fluvial Style Variations in Late Triassic-Early Jurassic Elliot Formation, Main Karoo Basin, South Africa. Journal of African Earth Sciences, Vol.38, pp.383-400.

Brasier, M.D., 1980. Microfossils, George Allen and Unain. London, 193p.

Clifton, H.E., 1982. Estuarine Deposition. In: Scholle, P.A. and Spearing, D., (eds), Sandstone Depositional Environments. A.A.P.G. Mem. No.31, pp.179-189.

Davidaon-Arnott, R.G. and Greenwood, B., 1976. Facies Relation Ships on a Barred Coast, Kouchibouguac Bay, New Brunswick, Canada, In: Davis, R.A. and Ethington, R.L. (eds.) Beach and Nearshore Sedimentation. Society of Economic Paleontologists and Mineralogists, No24, pp.149-168.

Dickinson, W.R. and Suczek, C.A., 1979. Plate Tectonic and Sandstone Compositions A.A.P.G. Bull. Vol. 63, pp.2164-2182.

Dill, H.G., Kharel, B.D., Singh, V.K., Bush, K. and Geyh, M, 2001. Sedimentology and Paleogeographic Evaluation of the Intermontane Kathmandy Basin, Nepal, During the Pliocene and Quqrternary: Implications for Formation of Deposits of Economic Interest, Journal of Asian Earth Scineces, Vol. 19, pp.777-804.

Dott, R.H., 1964. Wake, Graywake and Matrix-What Approach to Immature Sandstone Classification. Journal of Sedimentary Petrology, Vol. 34, pp.625-632.

Dunham, R.J., 1960. Classification of Carbonate Rock According to the Depositional Texture, in: Ham, W.E. (eds.) Classification of Carbonate Rock. A.A.P.G., Mem., 1, pp.108-121

Flugel, E., 1982. Microfacies Analysis of Limestone. Springer-Verlag, Berlin, 633p. Folk, R.L., 1974, Petrology of Sedimentary Rocks. Hemphill Publi. Comp. 182p. 
Hedley, R.H. and Adams, G.G., 1976. Foraminifera, Acadimic Press, London. 265p.

Hus K.J. and Siegenthaler, C., 1969. Preliminary Experiments on Hydrodynamic Movement Induced by Evaporation and Their Bearing on the Dolomite Problem, Sedimentology, Vol. 12, pp.11-25.

Kassab, I.I., 1978. Planktoic Foraminifera of the Subsurface Lower Teriary of Northern Iraq. Journal of Geologic Soceity of Iraq, Vol. 11, pp.119-159.

Levin, H.L., 1957. Micropaleontology of the Oldsman Limestone (Eocene) of Florida, Micropaleontology, Vol. 3, No. 2, pp.137-154.

Murray, J.W., 1973. Distribution and Ecology of Living Benthic Foraminiferids. Heinemann Educational Books, London, 274p.

Pautal, L., 1987. Foraminiferal Assemblages of Some Early Eocne Environments (Bays) from the Northern Corbieres, France, In: Hart, M.B, (eds) Micropalentology of Carbonate Environments, The British Micropalentologyic Society, pp.75-81.

Petters, S.W., 1979. Nigerian Paleocene Benthonic Foraminiferal Biostratigraphy, Paleontology and Paleogeography, Marine Micropalentology, Vol. 4, pp.85-99.

Pettijohn, F.J., Potter, P.E. and Siever, R., 1972. Sand and Sandstone, Springer Vaerlag, $618 \mathrm{p}$.

Reinson, G.E., 1997. Transgressive Barrier Island and Estuarine System, in: Walker, R.G. and James, N.P. (eds.) Facies Model, Response to Sea Level Change, Geol. Assoc. Canada, pp.179-194. 